\title{
Laws of Concentration and Centralization of Capital: A Modern Review
}

\author{
By SOURISH DUTTA*
}

\begin{abstract}
Though the basic (late 1860s) Marxian model, under the capitalist mode of production, assumes (more or less) perfect competitive or contestable ambiance within the market by means of a large number of trivial firms in each industry, Marx was cognizant of the growing size of firms, the subsequent dwindling of competition, and the evolution of monopolistic or anticompetitive power. Hence, the capital has the inclination for concentration and centralization in the hands of the richest and big capitalists. Actually, the concentration and centralization of capital are two capital accumulation (or self-expansion of capital) techniques. Such concentration and centralization of capital can be clearly detected at this modern time-especially in the USA-in the enormous occurrences of the mergers, acquisitions and conglomerates. In this assignment, henceforth, I will be trying to cultivate an analytical discussion about these two interlinked concepts and their implications and repercussions in this modern world of capitalism.
\end{abstract}




\section{Prologue}

The contemporary financial catastrophe of 2008 brings back the Marx's chief criticism of capitalism, i.e. the basic tendency for concentration and centralization of capital in the hands of richest capitalists in the modern form. They are often confused, but must be clearly distinguished. Marx explained it most famously in chapter 25 of volume 1 of Capital. Though his dynamic intellectual exploration engrossed in the industrial capital, the same tendency holds with respect to financial capital in present scenario.

"With the increasing mass of wealth which functions as capital, accumulation increases the concentration of that wealth in the hands of individual capitalists, and thereby widens the basis of production on a large scale and of the specific methods of capitalist production... It is the concentration of capitals already formed, destruction of their individual independence, expropriation of capitalist by capitalist, transformation of many small into few large capitals. This process differs from the former in this, that it only presupposes a change in the distribution of capital already to hand, and functioning ... Capital grows in one place to a huge mass in a single hand, because it has in another place been lost by many. This is centralisation proper, as distinct from accumulation and concentration."

In brief, by concentration we make out the upsurge of capital that is due to the capitalisation of the surplus value originated through accumulation of surplus value of labour. Indeed, snowballing concentration of capital occurs as individual capitalists mount up more and more capital, thereby growing the total amount of capital under their control. The size of the firm or economic unit of production is augmented consistently, and the degree of competition in the market be likely to be diminished; under centralisation we understand the joining together of various individual capital units which thus form a new larger unit. In fact, more vital cause for the lessening of competition is the centralisation of capital. Centralisation arises through a restructuring of already surviving capital in a method that assigns its proprietorship and control in fewer and fewer hands. Marx also upheld the view that bigger firms would be capable to attain economies of scale and thus produce at lesser average costs than would minor firms. 
However, concentration and centralisation, influence one another. A great concentration of capital accelerates the absorption of small-scale enterprises by large-scale ones; conversely, centralisation aids the increase of individual capital units and so accelerates the process of concentration. Beside this, recent experience of the financial crisis also conveys a new phenomenal dimension in the context of Marxian crisis in the capitalist mode of production. This phenomenon gives rise to the doctrine of "Too Big to Fail" i.e. According to some economists, when banks and financial corporations become too big, their failure has systemic implications, inflicting collateral damage on individuals who may have nothing directly to do with those banks or corporations. Governments then feel compelled to rescue these large entities in order to minimize the collateral damage, and the anticipation of such bailout promotes reckless behaviour.

\section{Rationale behind these laws}

The main logic behind these two laws of capitalism is the force of capital accumulation or the self-expansion of capital. The self-expansion of individual capital is accomplished through the appropriation of surplus value by maximizing the rate of profit, while the movement of the social capital leads to the equalization of rates of profit. And the combination of both of them gives a rise in contestable or competitive realisation of unlimited thrust for profit maximization.

Marx's model of accumulation, in this context, quite simple. Accumulation of capital, assuming constant productivity, increases demand for labor. Whether or not this leads to a rise in wages depends on the available population. But as more and more of the available population are brought into employment, wages will go up, which diminishes the rate of exploitation. But the mass of surplus-value can continue to rise because more laborers are employed. If at some point, for whatever reason, the mass of surplus value begins to diminish, then the demand for labor tails off, the pressure on wages slackens and the rate of exploitation recovers. Over time, therefore, we would likely see countervailing oscillations in wage and profit rates. Wages rise, accumulation slackens, wages fall back, profits and accumulation revive. Marx here describes an automatic adjustment system between the demand and supply of labor and the dynamics of accumulation. 
But the impacts of technological and organizational changes on productivity need to be placed in a central position in relation to the dynamics of accumulation. This leads Marx to elaborate at some length on the "law" of increasing value composition of capital in the manner already outlined. But while "the progress of accumulation lessens the relative magnitude of the variable part of capital ... This by no means thereby excludes the possibility of a rise in its absolute magnitude," because, as we have seen in the above case, more laborers can be employed to counteract the falling rate of surplusvalue. But once accumulation gets under way, the progress of increasing productivity also depends on processes of concentration and centralization of capital. Only in this way can all possible economies of scale be realized. Wealth increasingly concentrates on a few hands, he says, because at each round of accumulation the capitalist acquires an increasing mass of capital in the form of money power. Growth occurs at a compound rate, and the concentration of wealth and power accelerates, though in a way that is limited by the rate of surplus-value and the number of laborers employed. This process of concentration may also be partially offset, however, by the opening up of new small businesses in new lines of production. The fragmentation of the total social capital into many individual capitals, or the repulsion of its fractions from each other must also be taken into account. This is typical Marx: there are countervailing tendencies at work: concentrating on the one hand, subdivision and fragmentation on the other. Where is the balance between them? Who knows! The balance between concentration and decentralization is almost certainly subject to perpetual flux (countering any teleological interpretation of the evolution of machinery and large-scale industry).

Centralization, on the other hand, arrives at concentration of capital by a different path-takeovers, mergers, and the ruthless destruction of competitors. Marx observes that the development of capitalism always strengthens the centripetal tendency of individual capitals, and this happens for some obvious reasons:

- Competition and credit... Two most powerful levers of centralisation. The battle of competition is fought by cheapening of commodities. The cheapness of commodities depends, ceteris paribus, on the productiveness of labor, and this again on the scale of production. Therefore, the larger capitals beat the smaller. The increasing centralization of capital is furthered by the development of a credit system and of the corporate form of business organization. 
- "the progress of accumulation increases the material amenable to centralisation, i. e., individual capitals"... In other words, according to Kaushik Basu and Avinash Dixit, there are situations where it is better to have few large firms rather than many small ones. In itself, this is not new. There are special situations where arguments in favor of monopoly have been made. It is, for instance, believed that when it comes to creating money, it is best to have only one agent doing this in one economy, namely its central bank. And in industrial organization, complementary goods are better sold by a monopolist than by separate firms, so as to avoid double marginalization. In essence, they argue that having many firms may make them Too Small to Regulate (TSTR); conversely, having few firms makes it easier to regulate and administer them.

- $\quad$ "the expansion of capitalist production creates . . . the technical means necessary for those immense industrial undertakings which require a previous centralisation of capital for their accomplishment." Marx concludes: "Today, therefore, the force of attraction drawing together individual capitals, and the tendency to centralisation are stronger than ever before.

No matter what form the concentration of capital may take, the underlying motive is always the same. Capital wants to minimise the risks attaching to the multiformity of its enterprises. Fast-food businesses like Burger King, Pizza Hut and McDonalds use a predominantly centralised structure to ensure that control is maintained over their many thousands of outlets. The need to ensure consistency of customer experience and quality at every location is the main reason.

\section{The Repercussions}

Rapid centralization overtakes the slower processes of concentration through compound growth as the main vehicle for achieving the enormous financial scale required to implement entirely new rounds of productivity increase. Centralization can radically improve and increase the scale of production. We wouldn't be able to undertake many of the mega-projects of physical infrastructures (e.g., railways and ports) and urbanization (fixed and constant capital) without centralization (without involving the state). 
Adequate instruments of centralization are, therefore, absolutely critical to the dynamics of accumulation. But this poses the threat of monopoly power and contradicts the vision, so dear to classical political economy as well as to contemporary neoliberal theorists, of a decentralized market economy characterized by highly dispersed and individualistic decision making such that no one can corner or dominate the market. What Marx suggests here is that even if the market economy begins with small-scale, highly competitive firms, it is almost certainly going to be rapidly transformed through centralization of capital and end up in a state of oligopoly or monopoly. The result of competition, he says elsewhere, is always monopoly. Processes therefore exist internal to the capitalist dynamic that are inherently disruptive to the theory of how perfect markets work. The problem is that markets and the struggle for relative surplus-value cannot coexist for long without centralization kicking in and disrupting decentralized decision making in freely functioning markets.

This process of concentration has assumed a new form. We were already familiar with the growth of cartels and syndicates in which a number of like undertakings were associated to a certain degree, but still maintained substantial independence. Now we have to do with combines in which the independence of the amalgamated undertakings has disappeared, and in which the most heterogeneous enterprises are united under a single management. The number of U.S. commercial and savings bank institutions reached a peak of 14,495 in 1984 ; this fell to 6,532 by the end of 2010 . The ten largest U.S. banks held nearly $50 \%$ of U.S. deposits as of 2011 .

In modern form of capitalism, according to some calculations, the share of all banking industry assets held by the top 3 banks-Bank of America, J. P. Morgan Chase, and Citigroup — was (at the end of 2009) 51.8 percent, and by the top 6 banks - including Wells Fargo, Morgan Stanley, and Goldman Sachs - 76 percent. Measured another way, the assets of the 3 largest banks totaled 42.3 percent of the nation's gross domestic product, and of the 6 largest banks 62.1 percent of the nation's product. Bank deposits for all U.S. banks ranged between approximately 60-70\% of GDP from 1960 to 2006, then jumped during the crisis to a peak of nearly $84 \%$ in 2009 before falling to $77 \%$ by 2011. Clearly, those leading banks have grown over time in absolute size, in proportion to the financial sector of the U.S. economy, and in relation to the economy as a whole.

This concentration continued despite the subprime mortgage crisis and its aftermath. During March 2008, JP Morgan Chase acquired investment bank Bear-Stearns. Bank 
of America acquired investment bank Merrill Lynch in September 2008. Wells Fargo acquired Wachovia in January 2009. Investment banks Goldman-Sachs and MorganStanley obtained depository bank holding company charters, which gave them access to additional Federal Reserve credit lines.

As for India, it can be said in passing that there are enough indications of concentration and centralization taking place. However, it is quite evident that the credit system is well developed in India to facilitate centralization of capital. Commercial banks mobilize money resources that are scattered throughout the economy and put them at the disposal of big capitals. Such institutions as the Industrial Credit and Investment Corporation of India (ICICI), Industrial Finance Corporation (IFC), the Life Insurance Corporation of India (LIC), the Industrial Development Bank of India (IDBI), and the Unit Trust of India (UTI) have come lately into the picture to extend a helping hand to centralization of money capital through underwriting of new market issues, direct investment and credit, which are enjoyed mostly by bigger capitals.

The financial crisis of 2008 now looks more and more like a defining moment, a crisis of capitalism. Here we can now explore the notion of too-big-to-fail. Federal Reserve Chair Ben Bernanke also defined the term in 2010: "A too-big-to-fail firm is one whose size, complexity, interconnectedness, and critical functions are such that, should the firm go unexpectedly into liquidation, the rest of the financial system and the economy would face severe adverse consequences." He continued that: "Governments provide support to too-big-to-fail firms in a crisis not out of favoritism or particular concern for the management, owners, or creditors of the firm, but because they recognize that the consequences for the broader economy of allowing a disorderly failure greatly outweigh the costs of avoiding the failure in some way. Common means of avoiding failure include facilitating a merger, providing credit, or injecting government capital, all of which protect at least some creditors who otherwise would have suffered losses...If the crisis has a single lesson, it is that the too-big-to-fail problem must be solved."

Bernanke cited several risks with too-big-to-fail institutions:

- These firms generate severe moral hazard: "If creditors believe that an institution will not be allowed to fail, they will not demand as much compensation for risks as they otherwise would, thus weakening market discipline; nor will they invest as many resources in monitoring the firm's risk-taking. As a result, 
too-big-to-fail firms will tend to take more risk than desirable, in the expectation that they will receive assistance if their bets go bad."

- It creates an uneven playing field between big and small firms. "This unfair competition, together with the incentive to grow that too-big-to-fail provides, increases risk and artificially raises the market share of too-big-to-fail firms, to the detriment of economic efficiency as well as financial stability."

- The firms themselves become major risks to overall financial stability, particularly in the absence of adequate resolution tools. Bernanke wrote: "The failure of Lehman Brothers and the near-failure of several other large, complex firms significantly worsened the crisis and the recession by disrupting financial markets, impeding credit flows, inducing sharp declines in asset prices, and hurting confidence. The failures of smaller, less interconnected firms, though certainly of significant concern, have not had substantial effects on the stability of the financial system as a whole."

The evidence is clear: the concentration and centralization of financial capital are a problem for capitalism. That's the "Too Big to Fail" argument. The solutions to the "too big to fail" issue are controversial. Some options include breaking up the banks, reducing risk taking through regulation, bank taxes that increase for larger institutions, and increased monitoring. On April 10, 2013, International Monetary Fund Managing Director Christine Lagarde told the Economic Club of New York "too big to fail" banks had become "more dangerous than ever" and had to be controlled with "comprehensive and clear regulation [and] more intensive and intrusive supervision." ... Nonetheless, centralization can sometimes be countered by decentralization. Therefore, what we have to think about the relationship between concentration, deconcentration, centralization and decentralization. 


\section{References}

1. "On the Laws of Concentration and Centralization of Capital" Author(s): Ranjit Sau, Source: Social Scientist, Vol. 8, No. 3 (Oct., 1979), pp. 3-14

2. A Companion to Marx's Capital - David Harvey (Verso, 2010)

3. FRB: Testimony (Causes of the Recent Financial and Economic Crisis Before the Financial Crisis Inquiry Commission, Washington, D.C.) -- Chairman Ben S. Bernanke--September 2, 2010

- http://www.federalreserve.gov/newsevents/testimony/bernanke20100902a.htm

4. Capital accumulation - Wikipedia, the free encyclopedia

- http://en.wikipedia.org/wiki/Capital_accumulation

5. Too big to fail - Wikipedia, the free encyclopedia

- http://en.wikipedia.org/wiki/Too_big to fail

6. N.I. Bukharin: Imperialism and World Economy - Chapter 10: Reproduction of the Processes of Concentration and Centralisation of Capital on a World Scale.

- http://www.marxists.org/archive/bukharin/works/1917/imperial/10.htm

7. Too Small to Regulate - Policy Research Working Paper 6860 (The World Bank Development Economics Vice Presidency Office of the Chief Economist May 2014) - Kaushik Basu \& Avinash Dixit. 